\title{
Fabrizio Speziale. The Encounter of Medical Traditions in Nûr al-Dîn Šîrâzî’s 'Ilâjât-i Dârâ Šikôhî
}

\section{Živa Vesel}

\section{(2) OpenEdition}

1 Journals

\section{Édition électronique}

URL : http://journals.openedition.org/abstractairanica/40726

DOI : 10.4000/abstractairanica.40726

ISSN : 1961-960X

Éditeur :

CNRS (UMR 7528 Mondes iraniens et indiens), Éditions de l'IFRI

\section{Édition imprimée}

Date de publication : 1 décembre 2013

ISSN : 0240-8910

Référence électronique

Živa Vesel, « Fabrizio Speziale. The Encounter of Medical Traditions in Nûr al-Dîn Šîrâzî's 'llâjât-i Dârâ Sikôhî », Abstracta Iranica [En ligne], Volume 32-33 | 2013, document 407, mis en ligne le 01 juillet 2016, consulté le 27 septembre 2020. URL : http://journals.openedition.org/abstractairanica/40726 ; DOI : https://doi.org/10.4000/abstractairanica.40726

Ce document a été généré automatiquement le 27 septembre 2020.

Tous droits réservés 


\title{
Fabrizio Speziale. The Encounter of Medical Traditions in Nûr al-Dîn Šîrâzî’s 'Ilâjâtt-i Dârâ Šikôhî
}

\author{
Živa Vesel
}

\section{RÉFÉRENCE}

Fabrizio Speziale. « The Encounter of Medical Traditions in Nûr al-Dîn Šîrâzî’' ‘lâjjât-i Dârâ Šikôhî ». The Journal of Indian Medicine, 3, 2010, p. 53-67.

1 F.S. analyse différents aspects d'une compilation persane majeure, réunissant les connaissances médicales musulmanes (essentiellement avicénniennes) et indiennes, les 'Elājāt-e Dārā Šekūhì. parfois intitulée Tẹb-e Dārā Šekūhī ou DaHīre-ye Dārā Šekūhī. Rédigée pour le souverain moghol Dārā Šekūh, entre 1642-46, par Nūr al-dīn Šīrāzī, qui avait travaillé, par ailleurs, également pour Šāh Jahān et Awrengzeb, cette compilation est parmi ses derniers écrits d'importance. L'article de F.S. livre une mine de renseignements sur le contexte familial de Šīrāzī, sur le fonctionnement de la cour moghole quant aux sciences, sur l'influence des écrits de Šīrāzī dans les milieux anglais, etc. La description détaillée du contenu des 'Elājāt (d'après un MS complet conservé à la Bibl. de Majles) permet de mesurer, entre autres, la part qu'y tient la médecine religieuse (les dits du Prophète, le traité attribué au $8^{\mathrm{e}} \mathrm{Imam}$ ). L'ouvrage se compose de dix chapitres et se fonde sur les sources médicales arabes et persanes classiques, sources musulmanes de l'Inde et les sources indiennes. F.S. passe en revue également les autres écrits de Šīrāzī, notamment sa pharmacopée, Alfāz al-adwiye (1628), dédicacée à Šāh Jahān. C'est un article de base pour comprendre le phénomène de traductions du sanskrit en persan dans le milieu indien et du rôle qu'y a joué la pharmacopée. 


\section{AUTEURS}

ŽIVA VESEL

CNRS, Mondes iranien et indien, Paris 